\title{
KEANEKARAGAMAN PENGERTIAN YANG MELIPUTI ILMU DAN SENI
}

\author{
Jaduk Indiana \\ jadukforbid@gmail.com, Institut Seni Surakarta
}

\begin{abstract}
Abstrak
Tulisan ini berisi intisari keanekaragaman pengertian yang meliputi ilmu dan seni. Pemahaman ilmu dapat meningkatkan pemahaman dan fungsi yang sistematis, teratur, terorganisasi dan metodis. Masalah-masalah ini dicirikan seperti: 1) pemaparan pengertian ilmu yang mengandung pengetahuan luas; 2) tentang perbedaan pengertian ilmu dan pengertian seni; 3 ) faktor-faktor pengertian ilmu dan seni terhadap pengetahuan konsep-konsep; 4) tentang jumlah pengertian dasar seni seperti teknis, artistik, bentuk-bentuk artistik, dan keterampilan untuk mewujudkannya, serta pengetahuan isi yang melekat pada suatu realitas teknis dan bentuk secara artistic; 5) tentang pengembangan seni yang dapat dimbangi oleh penciptaan seni agar bisa mengetahui wujud ilmu dalam wujud seni. Pokok permasalah berupa macam-macam pengertian wujud ilmu dan wujud seni meliputi 2 hal, yaitu: (1) bagaimana wujud perbedaan pengertian ilmu dan seni? (2) apa hubungangan pengertian ilmu dan seni dalam konsep? Penelitian ini dikerjakan dengan pendekatan yang kerja etnografi yakni mendeskripsikan tentang keanekaragaman berdasarkan tiga aspek: pengertian, wujud ilmu, dan wujud seni. Bedasarkan hasil kajian ini dapat disimpulkan bahwa pengertian ilmu adalah metode. Mengingat di atas ditegaskan bahwa dalam karya seni memiliki kemiripan eksistensi dengan ilmu. Dengan demikian hakikat karya seni juga merupakan manifestasi ekspresi simbolik yang digagas, digarap, dan diwujudkan dengan menggunakan metode.
\end{abstract}

Kata Kunci: keanekaragaman pengertian; ilmu; seni

\section{DIVERSITY UNDERSTANDING OF SCIENCE AND ART}

\begin{abstract}
Qualitative research through the study of empirical views of the understanding of science and art, there is a meaning of usability as a from of science. Understanding of science can improve its function systematic, organized, organized and methodical. Here are 5 problems: 1). Understanding of science contains extensive knowledge. 2). Difference in understanding of science and understanding pf art. 3). Understanding factors of science and art of knowledge of concepts. 4). The amount of basic understanding of art such as technical, artistic, artistic forms, amd the skills to realize them, as well as content knowledge inherent in the reality of artistic forms. 5). The development of art that can be categorized by creating art in order to know the form of science in the form of science in the from of art. If the main problem is formulated understanding the from of science and art form includes 2 things, namely: (1). How Different Differences Understanding Science And Art. And (2). Is the relationship between Understanding of Science and Art in the concept. The purpose of this study is to find out the from of science and art from that contaons a diversity of understanding and knowledge. This research was carried out using an ethnographic system-oriented approach that is describing diversity based on there aspects: understanding, from of science and art form. The study concluded the notion of science is a method. Bearing in mind the above it is stressed that in works of art there are similarities in existence to science. The nature of works of art is also a manifestation of symbolic expressinos that were conceived, worked on and realized using methods.
\end{abstract}

Keyword: diversity understanding; science; art 


\section{PENDAHULUAN}

Wujud ilmu adalah proses yang dilakukan oleh ilmuwan dalam metode penelitian, yaitu terdiri dari sekumpulan aktivitas yang diarahkan pada penemuan dan perumusan himpunan pengetahuan secara sistematis yang berguna untuk meningkatkan pemahaman dan fungsi terapannya. IImu merupakan sistematis dalam arti teratur, dan terorganisasi, dan metodis. IImu juga merupakan proses, bukan hanya sebagai kumpulan suatu pengetahuan. Jadi, hakikatnya ilmu selain mengandung pengetahuan yang luas. pengetahuan juga merupakan yang dilakukan oleh ilmuwan. Pengertian ilmu juga bukan sekadar pengetahuan, bukan juga informasi atau koleksi fakta, data, dan bukan raelitas. Mengenai objek-objek yang diketahui dan tergelar di hadapan kesadaran ilmuwan dan orang-orang yang mempelajari ilmu. Ilmu merupakan kumpulan pengetahuan yang tersusun secara sistemik berdasarkan konsep-konsep yang dijelaskan. Akumulasi konsep-konsep yang tersusun secara sistemik menjadi sebuah teori landasan dalam menerapkan arti ilmu.

Pengertian ilmu adalah sistematis dalam arti teratur, terorgaganisasi, dan metodis. IImu juga merupakan proses, bukan hanya kumpulan suatu pengetahuan atau pengetahuan yang abstrak. Jadi, hakikat ilmu selain informasi dan pengetahuan adalah proses yang dilakukan oleh ilmuwan tersebut. IImu merupakan metodik, ilmiah yang mecangkup kebenaran umum mengenai objek studi. Sedangkan pengetahuan adalah sesuatu yang menjelaskan tentang adanya sesuatu hal yang diperoleh secara biasa atau dalam aktivitas sehari-hari melalui pengalaman empiris, kesadaran yaitu secara intuisi, bisa juga melalui informasi, dan lain-lain. Dengan demikian sebenarnya pengetahuan mempunyai cakupan lebih luas dan umum dari pada ilmu. Sehingga dalam tulisan ini sengaja disebut dengan menggabungkan keduanya, yaitu pengertian ilmu pengetahuan.

Keberadaan ilmu dan pengetahuan sama-sama pentingnya hidup dan kehidupan tidak boleh dipisahkan. Ilmu juga membentuk daya inteligensi yang melahirkan suatu kreativitas, keterampilan atau skill. Sedangkan pengetahuan membentuk daya moralitas keilmuan yang melahirkan tingkah laku kehidupan manusia. "Pengertian Pengetahuan adalah pengetahuan, yang didapat dari sebuah pengalaman. Sedangkan pengertian ilmu adalah pengetahuan yang didapat dalam fenomena jalan keterangan." Dari pemaparan di atas dapat ditemukan masalah sebagai berikut: (1) Bagaimana Wujud Perbedaan Pengertian Ilmu Dan Seni? (2) apa hubungangan pengertian ilmu dan seni dalam konsep?

Setelah mengetahui definisi pengertian ilmu pengetahuan, maka selanjutnya yang perlu dipahami adalah tentang ciri-ciri dalam suatu ilmu tersebut. Sebagaimana sudah disingung pada bagian sebelumnya, bahwa ciri-ciri dari pengertian ilmu pengetahuan sesuatu yang dikategorikan menjadi ilmu pengetahuan adalah karena ada suatu objeknya. Dengan demikian setiap pengertian ilmu pengetahuan ditentukan oleh objeknya. Ada dua macam objek ilmu pengetahuan, yaitu objek materi dan objek formal. Objek materi ialah sasaran atau bahan yang dijadikan objek penyelidikan suatu ilmu. Sedangkan objek formal ialah sudut pandang atau pandang mengenai objek materi tersebut. Sehingga dengan objek formal ini dapat dibedakan menjadi ilmu tertentu. Dengan demikian yang membedakan suatu ilmu dari yang lainnya ialah objeknya. Sehingga Sekalipun objek materinya sama, tetapi mempunyai sudut pandangnya atau objek formalnya berbeda. Bentuk kumpulan pengetahuan dalam ilmu dapat tergelar, dalam suatu pernyataan yang berbentuk deskripsi, preskripsi, eksposisi pola, dan rekonstruksi serta historis. 
Pada sebuah alam material, manusia dapat dikenali lewat pengalaman hidup sehari-hari. Sejak manusia lahir sampai saat pada kematiannya. Alam material ini juga dapat dipahami, dimengerti secara lebih mendalam lewat lembaga wujud ilmu. Ilmu pengetahuan dan teknologi adalah pemahaman manusia atas dunia material dan pemanfaatan dunia sebagai material itu agar bisa menjadi suatu kebutuhan kepentingan manusia. Rin (2015) berpendapat bahwa kegiatan yang berkaitan dengan seni adalah milik setiap manusia, dan hampir segala sesuatu yang direfleksikan di dalam seni adalah juga mengenai manusia. Dalam konteks lintas kurikulum, seni merupakan subjek yang dapat secara kreatif dianyam di dalam subjek-subjek yang lain atau dihubungkan dengan berbagai subjek dalam program pendidikan. Sebagai salah satu subjek di sekolah, seni bahasa merupakan sarana berkomunikasi yang dengannya kita hidup, bekerja, berbagi, dan membangun ide dan pemahaman mengenai masa kini, di samping juga merefleksikan masa lampau dan membayangkan masa depan (Rin, 2015: 68). Sedangkan wujudnya seni dapat memberikan pengetahuan dari bahasa lisan, tulisan, dan visual melalui kegiatan membaca, menyimak, berbicara, menulis, dan melihat. Setiap manusia mengalami berbagai peristiwa yang bersentuhan dengan elemen-elemen tentang seni sepanjang kehidupan. Wujud ilmu juga bisa dipahami dengan cara memahami dunia spiritual. Dapat pula dipahami oleh manusia dan juga dihayatinya lewat lembaga agama, lembaga filsafat, dan lembaga seni. Dengan demikian, wujud seni dapat dimasukan ke dalam lembaga kebenaran yang bersifat spiritual, sejajar dengan agama dan filsafat. Agama, seni, dan filsafat adalah dunia antara yang memungkinkan manusia yang masih material itu agar dapat memasuki alam spiritual atau alam kerohanian. Kegiatan seni lebih cenderung kepada kegiatan kerohanian dari pada kegiatan material atau kegiatan keilmuan.

\section{METODE PENELITIAN}

Jurnal ini menggunakan metode penelitian etnografi dengan observasi partisipan sebagai metode pengumpulan data. Peneliti terlibat secara aktif dalam mempelajari secara akademis, membaca studi pustaka dan wanwancara kepada seniman yang mengetahui kaeneragaman pengertian ilmu dan seni. Metode tersebut dapat membantu menemukan hasil penelitian dengan sumber data. Oleh karena itu, data hasil observasi dianalisis dengan metode fenomenologi. Dengan demikian metode itu menempatkan posisi yang diteliti sebagai sumber makna (Ahimsa-Putra). Makna ditentukan dari pengertian ilmu dan seni, yang mempunyai macam-macam keaneragaman.

\section{HASIL DAN PEMBAHASAN}

\section{a. Wujud tentang Pengertian Seni}

Wujud seni merupakan ekspresi dan rumusan pengetahuan secara empiris dan simbolik. Wujud seni yang secara empiris, yaitu yang berdasarkan konsep-konsep artistik yang dapat dijelaskan. Empiris adalah kumpulan pengetahuan tentang teknik, 
bentuk, keterampilan, dan nilai-nilai artistik. Rumusan pengetahuan seni itu terutama adalah pengetahuan tentang (1) teknis artistik, (2) bentuk-bentuk artistik, dan (3) keterampilan untuk mewujudkannya, serta (4) pengetahuan isi yang melekat pada suatu realitas teknis dan bentuk secara artistik, yaitu pengetahuan tentang nilai-nilai. Jadi, hakikatnya seni juga merupakan pengetahuan dan ekspresi serta pengetahuan yang secara tentang teknis, bentuk, keterampilan, dan nilai-nilai artistik yang terdefinisikan. Pengertian seni secara umum dapat dipaparkan yaitu seni adalah suatu aktivitas manusia untuk menciptakan berbagai produk atau artefak rupa, dan pertunjukan yang diciptakan oleh seniman/manusia yang di dalamnya ada sebuah keahlian mengekspresikan karya tersebut. Tujuan karya diciptakan sendiri agar dapat diapresiasi dan memberikan output atau nilai estetis.

Definisi seni adalah polemik yang tidak pernah berhenti sepanjang waktu. Seni merupakan bidang keilmuan sosial yang tidak memiliki batasan, sehingga pengetahuan mendasar tentang pengertian seni diperlukan agar perkembangan seni tetap terarah berdasarkan temuan hakikat seni oleh para penyumbangnya dari tahun ke tahun. Pemahaman seni sebagai pengetahuan yang pararel dengan suatu pemikiran-pemikiran bahwa ilmu adalah pengetahuan yang dinyatakan oleh Parker bahwa seni merupakan ekspresi, suatu ungkapan, suatu maksud, perasaan yang tidak semata-mata untuk tujuan praktis (Sumardjo, 2000). Ekspresi itu juga memiliki landasan yang bebas dan mandiri, dibuat dan dinilai pada dirinya sendiri.

Makna dari pengertian ungkapan adalah suatu maksud, perasaan, atau pikiranpikiran yang tidak lain adalah ungkapan sebuah pengalaman. Tidak pernah ada realitas tentang maksud, perasaan, atau pikiran yang terlepas bebas dari ikatan dari sebuah pengalaman. Pandangan mengenai ilmu di atas menstimuliasi adalah pemahaman, bahwa seni adalah manifestasi pengetahuan terpilih. Seniman menciptakan karya melibatkan suatu fenomena, terhimpun di dalam pikiran seniman pencipta tersebut. Baik secara alamiah atau secara ilmiah, dan secara common sense. Seni juga mempunyai isi pengetahuan tenang teknik, bentuk, keterampilan, dan nilainilai artistik yang diformalisasikan dan dimanifestasikan oleh seniman pencipta ke dalam suatu kerangka artistik dan bentuk-bentuk empiris tertentu. Formulasi dan manifestasi itu memungkinkan adanya penghayatan terhadap realitas artistik pada bentuk-bentuk empiris, sehingga dapat menimbulkan interpretasi dan penghayatan dan nilai-nilai secara multi-interpretasi.

Wujud seni memang perlu mendapat perhatian dari pakar-pakar seni, karena selama ini tidak didukung dengan usaha-usaha pengembangan pemikiran secara epistimologi sebagai basis utamanya. Pengembangan seni dimibangi oleh pencitaan seni agar bisa mengetahui wujud ilmu dalam wujud seni yang selama ini tidak ditopang dengan pilar eksistensinya sebagai ilmu pengetahuan, dan wujud seni berbeda dengan wujud ilmu. Pada akhirnya krisis epistemologi telah terjadi dalam pengembangan penciptaan seni dan juga aktivitas pencitaan seni. Krisis ini juga mengindikasikan tidak adanya pengembangan sebagai penciptaan seni yang memadai. Agar perkembangan wujud seni dalam paradigma yang tidak memadai dan dengan cara mengindikasikan tidak hanya ada karya baru atau sarana yang menyakinkan mengenai adanya suatu karya baru dan bisa mempunyai yang bobotnya artistik dan secara signifikan, baik dalam dunia akademik atau dalam dunia seni. Agar terdapat suatu wujud ilmu. Kecenderungan pada umumnya karya-karya baru adalah yang memiliki suatu kandungan artistik, berupa pengulangan konstrak, yaitu bentuk empiris, dan sistem artistik dalam karya-karya yang secara signifikan sebelumnya. 
Pada umumnya pengertian wujud seni yang mempunyai karya seni bisa diekpresikan melalui gagasan dan perasaan. Sedangkan alam tidak mengandung makna ekspresi semacam itu. Kedua, dalam karya seni atau karya seni, orang dapat bertanya, "apa yang ingin dikatakan dalam karya seni untuk mengetahui wujud seni ini atau apa yang dimaksud karya ini?". Tetapi kita tidak pernah bertanya serupa ketika menyaksikan keindahan matahari terbenam di pantai, menyaksikan bentuk awan senja, derai air terjun, atau gemuruh suara ombak. Jadi, bentuk wujud seni dan karya seni selalu membawa makna tertentu dalam dirinya dan ada usaha juga untuk komunikasi seni dengan orang lain. Dalam keindahan alamiah hal itu tak terjadi.

Kecantikan seorang wanita kita nikmati sebagai indah begitu saja. Tetapi dalam wujud seni untuk menciptakan sebuah karya seni, seorang wanita tua atau buruk rupanya dapat menjadi indah. Sedangkan wanita cantik justru tidak indah dalam wujud seni yang gagal, Ketiga, wujud seni dapat meniru alam, tetapi alam mungkin meniru wujud seni secara artefak. Pengertian seni juga mempunyai tujuan yaitu seni hanyalah alat untuk mencapai atau menyampaikan sesuatu', maka jelas golongan ini mengartikan seni juga bisa menjadi alat. Salah satu penganut pikiran ini adalah mereka yang bersemboyan 'seni untuk masyarakat, seni untuk moral, atau seni demi agama'. Saya juga berpendapat Bangsa Indonesia sejak dulu menganut pemikiran ini. Dalam Bahasa Jawa atau bahasa daerah yang lain tidak ada padanan kata untuk art yang diterjemahkan menjadi kata seni yang semula berarti halus, kecil. Ini juga menimbulkan tanda tanya. Bagaimanapun, memang sulit mencari padanan kata 'seni' dalam bahasa daerah. Dalam Bahasa Jawa dikenal kata yang mirip dengan itu, yakni kagunan, yang artinya berguna, kegunaan bagi manusia. Filosofi seni orang Indonesia dahulu adalah menganggap seni sebagai alat, seni untuk sesuatu (agama, moral, hiburan, pengetahuan, dan lain-lain).

Seni diciptakan demi keindahan semata. Semboyan yang terkenal dalam hal ini adalah 'seni untuk seni'. Dalam pemikiran ini, seni bukan 'berpikir tentang sesutu'. Seni adalah sebuah empati, keterleburan pribadi ke dalam sesuatu kita sebut seni. Seni itu suatu kualitas yang hanya dapat dialami, dihayati. Seni itu suatu proses yang membawa ke sebuah kompleks pengalaman. Seni itu juga bisa disebut imajinasi di luar realitas empiris manusia di sini dan masa sekarang. Imajinasi adalah alat moralitas manusia secara ilmiah. Keindahan itu dengan sendirinya benar dan baik, logis, dan etis. Kualitas seni boleh dikatakan bersifat transcendental. Keindahan dalam seni bukan berasal dari dunia ini atau dari hidup sehari-hari. Kualitas emosi, bentuk, struktur, dan ekstrinsik dalam seni harus berada di luar keseharian kita. Dengan pencapaian demikian itu, seni adalah pembebasan. Seni memasukkan manusia ke dalam sebuah pengalaman yang berkualitas khusus. la menggapai sesuatu yang berada di luar tempat dan waktu, di luar konteks zamannya. Maka, kebenaran seni juga tidak dapat diukur dari ukuran konteks zaman, tempat, dan waktu tertentu.

Seni mengambil jarak imajinatif dengan realitas. Dalam hubunganya dengan moralitas, seni bertujuan menemukan dan mengungkapkan keindahan semesta, karena adanya sesuatu yang agung dan mulia sesuai dengan apresiasi terhadap kosmos. Seni dalam pandangan kaum pecinta keindahan ini tidak bekerja secara langsung mengekspresikan ide atau sikap, tetapi mewujudkan sebuah pengalaman hidup suatu wujud. 'Seni sepenuhnya merupakan kepuasan keindahan tanpa mengenal kata pamrih'. Sementara itu, kaum penganut 'seni untuk masyarakat' menekankan nilai-nilai eksistensial, nilai-nilai yang terjadi di sini dan di masa sekarang. Maka karya demikian itu dapat dinilai dengan ukuran kontekstual, baik agama, politik, moral, dan sosial. 


\section{b. Perbedaan Pengertian antara IImu dan Seni dalam Penciptaan Seni}

Dalam fenomena pengertian seni bisa juga dengan cara penelitian ilmiah dan mengindikasikan adanya pengakuan, anggapan, dan pandangan bahwa dalam pencitaan seni merupakan suatu kegiatan yang pada akhirnya menimbulkan pengetahuan dan ilmu yang mengandung pengertian, sehingga dalam pengembangan program studi pencitaan seni yang dapat diposisikan sederajat dengan program studi yang lain, agar bisa mengindikasikan adanya upaya untuk pengembangan bidang penciptaan seni agar bisa disiplin sebagai suatu pengertian ilmu pengetahuan. Pengertian seni juga menyangkut penghayatan dalam sebuah struktur pengalaman estetis, sedangkan ilmu menyangkut pemahaman rasional-empiris terhadap suatu objek ilmu. Pengertian seni menyangkut masalah penciptaan, sedangkan pengertian ilmu menyangkut masalah penemuaan. Dengan demikian seni menghasilkan sesuatu yang belum ada sebelumnya menjadi ada. IImu juga selalu berdasarkan apa yang sudah ada. Pendekatan ilmu menggunakan perangkat intelegensia, analisis, dan pengamatan terhadap dunia material. Pendekatan seni mengarahkan pandangannya ke dalam lubuk batin manusia, di sudut-sudutnya yang tersembunyi dan rahasia. Metode yang dimaksud di sini adalah suatu cara untuk mendapatkan ilmu pengetahuan yang benar. Metode merupakan cara-cara penyelidikan yang bersifat keilmuan, yang sering disebut metode ilmiah (scientific methods). Metode ini perlu agar tujuan keilmuan yang berupa kebenaran objektif dan dapat dibuktikan bisa tercapai.

Dengan metode ilmiah, kedudukan pengetahuan berubah menjadi pengertian sebuah ilmu pengetahuan, yaitu menjadi lebih khusus dan terbatas lingkup studinya. Kata metode berasal dari bahasa Yunani, 'methodos' berarti jalan atau cara untuk menuju suatu arah. Metode dapat pula diartikan uraian ilmiah penelitian atau metode ilmiah. Dengan demikian, metode dapat pula diartikan cara bertindak menurut aturan tertentu dengan tujuan agar aktivitas dapat terlaksana secara rasional dan terarah supaya dapat mencapai hasil yang sebaik-baiknya. Satu lagi hal yang penting adalah bahwa cara kerja jenis metode ilmiah yang pastilah melakukan aktivitas analisis dan sintesis dengan perlatan pemikiran induktif dan deduktif. Analisis artinya memisahmisahkan dari suatu keseluruhan ke dalam bagian-bagian, komponen-komponen sehingga membentuk keseluruhan. Adapun induksi adalah suatu proses kegiatan penalaran yang bertolak dari suatu bagian, kekhususaan, dari yang individual menuju ke suatu keseluruan, umum dan universal. Sebaliknya, dedukasi adalah suatu proses kegiatan penalaran yang bertolak dari keseluruhan umum dan universal menuju ke suatu bagian, kekhususan, dan individual.

Sistem berarti menunjukan adanya saling keterkaitan dan saling hubungan antara pengertian satu dengan yang lainya. Hal ini berarti bahwa pengertian dari pengetahuan-pengetahuan yang terkandung di dalamnya harus saling berhubungan antara satu dengan yang lainya secara fungsional dalam satu system, sehingga adanya sistem bagi ilmu pengetahuan itu diperlukan agar jalanya penelitian lebih terarah dan kosisten dalam mencapai tujuanya, yaitu kebenaran ilmiah. Dengan demikian dapatlah dikatakan bahwa fungsi sistem bagi pengertian ilmu pengetahuan adalah mutlak adanya. Suatu sistem berfungsi aktif yang menggerakan dan mengarahkan langkah-langkah yang telah ditentukan di dalam metode agar ditemukan daya kerja metode itu secara konsisten, sehingga pencapaian tujuan kebenaran ilmiah lebih dapat terjamin datanya. Kebenaran ilmiah maksudnya adalah suatu pengertian sebuah pengetahuan yang jelas dan pasti kebenaranya menurut norma-norma keilmuan. Pengertian Kebenaran ilmiah cenderung bersifat objektif, di dalamnya 
terkandung sejumlah pengetahuan menurut sudut pandang yang berbeda-beda, tetapi saling bersesuaian. Dengan demikian Adanya kebenaran itu selalu dihubungkan dengan pengetahuan manusia sesuatu yang subjek berfungsi untuk mengetahui dalam suatu objek. Jadi, kebenaran itu ada pada seberapa jauh subjek mempunyai pengetahuan mengenai objek. Pada umumnya pengertian Seni juga menghadirkan kualitas pengalaman yang unik dan spesifik, seperti soal kesepian, penderitaan, kemuliaan dan keagungan, keperkasaan, kesedihan, yang jelas tidak dapat dirumuskan dalam bidang keilmuan. Dalam beragam ilmu segalanya yang kuantitatif, dan terukur dalam parameter tertentu.

\section{c. Objek perbedaan antara pengertian dari pengertian ilmu dan seni}

Objek dalam suatu pengertian ilmu adalah kenyataan alam dan nonalam sehingga muncullah keseragaman, identitas, dan kausalitas.Pengertian objek seni adalah karakter sebuah kualitas yang selalu bersifat individual, unik, bebas, spontan, dan ajaib, penuh pesona dan kejutan yang segar dan baru, seolah-olah baru ada dari ketiadaan. Pengertian ilmu dalam seni dapat meletakan sebuah karya seni yang fungsinya sebagai objek pengamatannya, sehingga karya seni dalam ilmu bukan untuk dihayati, melainkan untuk dipahami secara rasional. Pemahaman terhadap karya seni ini akan membantu dalam menghayati karya dalam bidang seni tersebut. Jadi, pengertian ilmu-ilmu seni adalah alat yang membantu manusia untuk dapat belajar mendalami penghayatan karya seni. pengertian seni juga tidak jauh beda dari pandangan tentang ilmu, karena seni adalah prosedur untuk mengembangkan dan menawarkan pengetahuan. Pengertian ilmu mempunyai perbedan yang harus dibedakan dengan seni. Seni itu soal penghayatan, sedangkan ilmu adalah soal pemahaman. Seni juga bisa untuk dinikmati, sementara ilmu untuk memahami, sebuah pengetahuan dari berbagai eksistensi dan pengalaman. Seperti misalnya contoh orang juga dapat ahli dalam menikmati seni dan mampu menunjukan karya seni yang bagus dan yang lain kurang bagus.

Penggemar seni dapat menilai seni berdasarkan pengalamannya, dalam bergaul dengan cara mempelajari ilmu menjadi sarana penciptaan seni, agar bisa mencari perbedaan dalam mengartikan berbagai fenomena karya seni. Tetapi, seorang ahli seni yang sesungguhnya akan dapat memilih karya seni yang baik dan sekaligus dapat mempertanggungjawabkan mengapa karya seni dianggap bagus. Di satu pihak terdapat peristiwa cinta seni tanpa memahami, dan di pihak lain mecintai dengan pemagaman. Contoh sebagai berikut: Cinta tanpa memahami dapat tidak setia dan tidak awet. Dalam pengalaman hidup kesenian di Indonesia, sepintas lalu dapat disimpulkan lebih banyak pecinta seni, sehingga ada yang kurang memahami ilmu dari pada ilmu seni. Dengan demikian dari pada pecinta ilmu seni yang memahami lengkap dengan ilmunya sudah menjadi tugas pengeluas atau kritikus seni untuk betanggung jawab atas penghayatan dan penikmat serta pemahaman pengertian seni dan ilmu.

\section{d. Persamaan tentang Pengertian Ilmu dan Seni}

Seni yang hakikatnya memiliki kesetaraan dengan ilmu juga dapat dipahami sebagaimana memahami ilmu. Artinya, seni juga dapat dipahami sebagai disiplin yang pengungkapannya menggunakan metode artistik, bukan metode ilmiah, yang tujuanya untuk menyampaikan dan menstimuliasi penghayatan aksiologis atas fenomenafenomena tertentu berkenaan dengan pola-pola umum, hukum-hukum maupun dalil- 
dalil yang dipahami dan dihayati seniman pencipta tersebut. Interpretasi dan evaluasi seni sangat erat hubungannya dengan ilmu. Hasil-hasil persamaan ilmu dan seni dapat berguna bagi siapa saja, baik dalam penciptaan maupun penghayatan. Pada umumnya seni juga memiliki esistensi yang sama dengan ilmu disebabkan karena adanya landasan yang bebas dan yang mandiri dan dibuat atau dinilai pada dirinya sendiri.

> Goode (dalam Sumardjo, 2000) mengatakan bahwa ilmu adalah "a method of approach to the entire empiricial world. i.e the world which is susceptible of experience by man", suatu metode pendekatan terhadap seluruh dunia pengalaman, yaitu dunia yang mungkin dapat menjadi pengalaman manusia. Pengertian seni juga tidak jauh dari pandangan Goode tentang ilmu, karena seni adalah metode pendekatan terhadap dunia pengalaman manusia, terutama pengalaman yang membangkitkan kesadaran tentang pengertian nilai.

> Sedangkan menurut Hoult (dalam Sumardjo, 2000) mengatakan bahwa ilmu adalah "a procedure for developing reliable knowledge about the probability that, under specified conditions, particular relationship exist between given empirical phenomena, and the resulting bodies of knowledge each of which is organized into a coherent system of general propositions", suatu prosedur untuk mengembangkan pengetahuan terpercaya mengenai probbilitas bahwa, di bawah syarat-syarat yang ditegaskan, hubungan-hubungan khusus terjadi di antara fenomena empiris yang ditentukan dan kumpulan-kumpulan pengetahuan yang dihasilkan yang masingmasing disusun menjadi suatu sistem terpadu dari proposisi-proposisi umum.

Pengertian seni juga tidak jauh dari pandangan Hoult tentang ilmu karena seni adalah prosedur untuk mengembangkan dan menawarkan pengetahuan berikut nilainilai yang dikandung secara simbolik. Pengertian seni juga eksis dengan syarat-syarat tertentu, boleh jadi juga memiliki hubungan dengan fenomena-fenomena empiris yang menjadi objek penciptaannya dan wujud artistik yang bersifat simbolik pada hakikatnya juga merupakan kumpulan pengetahuan yang digarap, dirumuskan, dipertimbangkan, dan ditemukan dalam rangka meningkatkan kualitas kesadaran jiwa penghayat terhadap suatu nilai-nilai. Ahli epistemologi lain yang berpendapat tentang hakikat ilmu adalah Lindsay, yang mengatakan bahwa ilmu adalah "a method for description, creation and understanding of human experience", suatu metode untuk penggambaran, kreasi atau penciptaan, dan pemahaman terhadap pengalaman manusia (Sumardjo, 2000).

Pandangan Lindsay tentang ilmu di atas malah dapat secara langsung diinterpresentasikan bahwa disiplin penciptaan seni sebagai ilmu. Hakikatnya pengertian seni adalah ungkapan suatu wacana secara simbolik dan tidak bertujuan praktis. Oleh karena itu, penciptaan seni adalah penciptaan wacana simbolik. Pengertian wacana adalah ekspresi gagasan-gagasan atau ekspresi yang disajikan berkenaan dengan berbagai macam gagasan. Pengertian Seni sebagai ekspresi yang menyajikan berbagai macam gagasan tentu juga eksis dalam bentuk-bentuk penggambaran, kreasi, atau penciptaan, dan pemahaman terhadap pengalaman manusia.

Tidak pernah ada karya seni yang tidak menyajikan penggambaran suatu kreasi atau penciptaan dan pemahaman seniman terhadap pengalaman yang disadarinya. Ahli epistemologi selain Lindsay yang berpendapat tentang hakikat ilmu adalah Lockyer. la yang menyatakan bahwa ilmu adalah "simply the employment of means adequate to the attainment of desired end, whether end be the constitutions of a government, the organization of an army or navy, the spread of learning, or the 
repression of crime", semata-mata penggunaan sarana yang memadai untuk pencapaian suatu tujuan yang diinginkan, apakah tujuan itu adalah pembentukan suatu pemerintahan, pengorganisasian tentara atau angkatan laut, penyebaran pengetahuan ataupun represi terhadap tindakan kriminal (Haines dalam Sumardjo, 2000). Pada hakikatnya seni adalah sarana untuk pencapaian tujuan. Namun tujuan seni bukan ditujukan untuk keperluan praktis seperti pembentukan suatu pemerintahan, pengorganisasian tentara atau angkatan laut, penyebaran pengetahuan ataupun represi terhadap tindakan kriminal sebagaimana dipahami oleh Lockyer tentang ilmu. Tujuan pengertian seni adalah untuk membangkitkan perasaan sadar melalui penghayatan, kegembiraan, dan keharuan terhadap nilai-nilai, terutama adalah nilainilai rohani yang wigati yang penting, yang menyadarkan manusia pada sangkan paranig dumadi, asal usulnya hidup dan kehidupan yang harus dijalani sebagai manusia. Ahli lain yang menegaskan ilmu merupakan metode adalah sebagai berikut;

$>$ Taylor, ia mengatakan bahwa "science, in its widest sense, is a systematic method", ilmu, dalam arti yang paling luas, adalah metode yang sistematis (Sumardjo, 2000).

> Lindsay dengan tegas mengatakan bahwa "science is a method for description, creation and understanding of human experience", ilmu adalah suatu metode ntuk mendeskripsikan mencipta, dan memahami pengalaman manusia (Sumardjo, 2000).

\section{SIMPULAN}

Pandangan-pandangan di atas telah menegaskan bahwa pengertian ilmu adalah metode. Mengingat di atas ditegaskan bahwa dalam karya seni memiliki kemiripan eksistensi dengan ilmu. Oleh karena itu, di sini dapat ditegaskan bahwa hakikat karya seni juga merupakan manifestasi ekspresi simbolik yang digagas, digarap, dan diwujudkan dengan menggunakan metode. Dengan demikian maka hakikat seni adalah metode untuk menyatakan ekspresi, metode untuk mengungkapkan suatu maksud, perasaan atau pikiran yang tidak semata-mata untuk tujuan praktis. Pada penciptaan karya seni adalah metode mengungkapkan maksud dengan landasan yang bebas dan mandiri, dibuat dan dinilai pada dirinya sendiri, yaitu pada ungakapan suatu maksud itu sendiri.

Kritik-kritik atau saran guna membangun penyusunan dalam penyempurnaan makalah ini sangat diharapkan karena dengan penuh kesadaran bahwa makalah ini masih jauh dari sempurna. Penulis menyadari dalam penyusunan makalah ini tidak lepas dari bimbingan, pengarahan, saran-saran maupun petunjuk dari pihak lain. Maka pada kesempatan kali ini penulis ingin menyampaikan terimakasih kepada semua pihak yang telah membantu dalam proses penyusunan jurnal ini.

\section{DAFTAR PUSAKA}

Susanto. A. 2013. Filsafat IImu, Suatu Kajian dalam Dimensi Ontologis, Epstimologis, dan Aksiologis. Jakarta: PT. BUMI AKSARA.

Sumardjo, Jakob. 2000. Filsafat Seni. Bandung: Penerbit ITB.

Sunarto, Bambang. 2013. Epistemologi Penciptaan Seni. Yogyakarta: Penerbit IDEA press Yogyakarta. 
Rin, Surtantini. 2015, Pembelajaran Seni Bahasa Dalam Konteks Lintas Kurikulum Melalui Drama. Jurnal Kajian Seni. PPPPTK Seni dan Budaya Yogyakarta. 